\title{
Rationality and Validity of ITKs on General Agriculture by Tribal Farmers in Telangana Region
}

\author{
N. Praveen*, I. Sreenivasa Rao and V. Sudha Rani \\ Department of Agricultural Extension, College of Agriculture, Professor Jayashankar \\ Telangana State Agricultural University, Hyderabad - 500030, Telangana, India \\ *Corresponding author
}

\section{A B S T R A C T}

This study was conducted in Adilabad, Khammam and Warangal districts of Telangana. Ex post-facto research design was followed in this study, since different variables chosen

\section{Keywords}

Rationality, Validity of ITKs, Agriculture, Tribal Farmers

\section{Article Info}

Accepted: 04 October 2018 Available Online: 10 November 2018 for the study had already occurred. An effort was made to document the indigenous technology of tribal farmers. For testing the rationality of the ITKs, a questionnaire containing lists of ITKs was prepared and exposed to the scientists for judging their rationality and validity on a three point scale wherein, 3 is rational, 2 undecided and 1 is irrational. The mean score was calculated by summing the scores overall and divided by the number of judges for a given item and if it is more than two then the item was considered as rational and less than two was considered as irrational. For validity, the scientists were asked to find out the valid ITKs among rational ITKs which were validated, tested and verified on the basis of research. Out of 63 ITKs in general 41 ITKs $(65.08 \%)$ were judged rational by the scientists and 22 ITKs (34.92\%) were judged as not rational. Out of 41 rational ITKs of general agriculture, 36 ITKs were found valid by the scientists as the test verification was already completed for those ITKs like ploughing, levelling, presowing season for land preparation and incorporation of FYM in the soil for improving soil fertility were judged as rational as well as valid by the scientists.

\section{Introduction}

Tribals in course of their close interactions with nature and natural resources have to make certain decisions to solve the problems they encounter in their day to day life while managing the land and environmental resources for survival. Compelling situations motivate them to generate knowledge out of necessity. Therefore, indigenous knowledge so developed is based on necessities, curiosity and observations of ethnic groups to mitigate the immediate situations. Tribals in the districts are mostly below poverty line and alienated from development and basically survive on subsistent agriculture which is primitive in nature.

Tribals are generally steeped with a number of superstitious and primitive beliefs related to crop production and protection practices. Some of the beliefs play a vital role in deciding the sustainability of a technology to reduce the cost of cultivation and to propagate eco-friendly agriculture (Sundaramari and Ranganathan, 2003). According to Haverkort 
(1995) ITK is the actual knowledge of a given population that reflects the experiences based on tradition and includes more recent experiences with modern techniques. ITKs are broad based, ecologically sound, environmentally safe, socially acceptable and economically resilient. Identifying, documenting and incorporating the indigenous knowledge systems into agriculture extension organizations is essential to achieve sustainable agriculture development (Rajasekharan, 1993). Hence, an attempt has been made in this study with the following specific objectives.

To identify and document the indigeneous agricultural practices of tribal farmers in Telengana region of Andhra Pradesh.

To ascertain the scientific rationality and validity of ITKs on General Agriculture of Tribal Farmers in Telangana.

This can create favourable attitude towards rational ITKs for quick dissemination of technology and increase the area under cultivation.

\section{Materials and Methods}

The study was conducted by adopting an expost facto research design method to study the rationality and validity of ITKs towards indigenous agricultural practices. The study was conducted in Adilabad, Khammam and Warangal districts of Telangana. From each district four mandals were selected, and from each mandal three villages were selected and from each village six farmers were selected for this study by following random sampling method. Thus the study represents 3 districts, 12 mandals, 36 villages and 216 respondents. For testing the rationality of the ITKs, questionnaires containing different lists of ITKs pertaining to Plant Protection and Postharvest technology were prepared and exposed to the scientists for judging their rationality and validity by giving three point scale viz., a score of 3 for rational, 2 for undecided and 1 for not rationale. The mean score was calculated by summing the overall scores and divided by the number of judges for a given item and if it was more than two then the item was considered as rational and less than two was considered as irrational. For validity, the scientist respondents were asked to find out the valid ITKs among rational ITKs which were validated, tested and verified on the basis of research in the State. Out of 63 ITKs in general 41 ITKs $(65.08 \%)$ were judged rational by the scientists and 22 ITKs $(34.92 \%)$ were judged as not rational.

\section{Results and Discussion}

It could be observed from the above Table 1 that out of 63 ITKs in general 41 ITKs $(65.08 \%)$ were judged rational by the scientists and 22 ITKs $(34.92 \%)$ were judged as not rational.

Out of 41 rational ITKs of general agriculture, 36 ITKs were found valid by the scientists as the test verification was already completed for those ITKs. ITKs which are recommended by the scientists in agriculture like ploughing, levelling, pre-sowing season for land preparation and incorporation of FYM in the soil for improving soil fertility were judged as rational as well as valid by the scientists.

The ITK No.1 was judged as rational and valid because during the season farmers were advised to incorporate FYM in the soil to improve soil fertility. Whereas ITK No.16 was found rational but validation of ITK was not taken up by the scientist till date.

The ITK No.17, 18 were found irrational because they don't have any scientific base and these are only beliefs and traditions of the tribal farmers. 
The ITK No.7 \& 10 were judged rational and valid by the scientists because nullaka (gaddi) weed which can be made into ropes, utilize for taking water from open wells, used for preparation of the cots, and wild amla is used for preparation of pickles for consumption.

The ITK No.15 \& 20 were judged rational and valid because during storage tribals mix neem leaves and ash with the seeds to avoid attack of pests and diseases because neem leaves has insecticidal properties and cow dung ash and Yerra thega repels the insects, when attacked.

The ITK No.25 was judged rational and valid because when paddy straw is kept at certain height on bamboo sticks, the animals, insects and termites attack may not occur.

The ITK No.26, 27 and 29 indicated the religious customs of tribal's performed in agricultural operations and all those ITKs were found irrational because they have no scientific evidence behind them.

They are only beliefs and tradition of tribal people, strictly followed in their living.

The ITK No. 3, 4, 12, 14 and 28 were related to predictions about rainfall by the tribals and all the ITKs were judged irrational and not valid by the scientists. It is only their belief.

The ITK No. 6 was found rational and valid because rainfall during Telugu months viz. in uttara and hasta are very important to raise the winter crops viz., Sorghum, Bengalgram and Cotton.

The ITK No.30, 31, 33, 34 and 35 were judged rational and valid by the scientists. The possible cause behind the rationality of these ITKs was due to the appropriate mixed crop combination followed by the farmers and they are economically feasible, even if one crop fails they can get income from another crop.
The ITK No.21, 22, 23 and 24 were found rational and valid ITKs. The powdered redgram leaf is used as animal feed and the sticks are used as fuel, bottle guard as border crop around groundnut field where they get additional income.

The farmers are well aware of the harvesting indices of cow pea which is found rational and valid.

The ITK No.36 indicated the incorporation of FYM in the soil for improving soil fertility, soil microorganism and soil structure and was judged rightly as rational and valid by the scientists.

The ITK No. 37 incorporation of ash in the soil for improving fertility and reclamation of soil was found rational but not valid.

Ash contains small quantities calcium and sulphur which can improve fertility but reclamation of soil was not validated.

The ITK No. 59 was judged rational because during storage of food grains tribals use big drums made up of clay and coated with paste of cow dung to avoid attack of pests and diseases because cow dung has insecticidal properties which repels the insect.

The ITK No 38 and 39 were judged as rational and valid because deep ploughing after every shower during the pre-sowing season is necessary for the crop to conserve enough moisture remove weeds and ensure good crops.

The ITK No 41 and 42 were judged rational and valid because deep ploughing is practiced during summer to improve water holding capacity and conserve enough soil moisture.

Laying stone bands across the slope in the field helps in preventing soil erosion. 
Table.1 Rationality and validity of ITKs on general agriculture

\begin{tabular}{|c|c|c|c|c|}
\hline $\begin{array}{l}\text { ITK } \\
\text { No. }\end{array}$ & Indigenous Technical Knowledge (ITKs) & $\begin{array}{l}\text { Mean } \\
\text { score }\end{array}$ & $\begin{array}{l}\text { Ratio- } \\
\text { nality }\end{array}$ & $\begin{array}{l}\text { Vali- } \\
\text { dity }\end{array}$ \\
\hline 1. & During the season they incorporate FYM in the soil to improve soil fertility. & 2.71 & $\mathrm{R}$ & $\mathrm{V}$ \\
\hline 2. & $\begin{array}{l}\text { During the month of April and May they plough the soil to expose to hot sun which kills soil } \\
\text { borne seeds and weeds. }\end{array}$ & 2.52 & $\mathrm{R}$ & V \\
\hline 3. & Wind blowing from the north-west would cause rains. & 1.09 & IR & - \\
\hline 4. & $\begin{array}{l}\text { Sorghum does not come up well if lightening occurs in this aridra, ponarvasu and phushya, } \\
\text { rainfall. }\end{array}$ & 1.14 & IR & - \\
\hline 5. & If thunderbolt occurs on Aridra (June 21) it is good for most of the crops. & 1.91 & IR & - \\
\hline 6. & $\begin{array}{l}\text { Rainfall in Uttara and Hasta are very important for winter crops viz., sorghum, bengalgram, } \\
\text { cotton. }\end{array}$ & 1.04 & $\mathrm{R}$ & V \\
\hline 7. & Nulaka (gaddi) grown in the forest i.e. used for making ropes and sell in the local markets. & 2.34 & $\mathrm{R}$ & V \\
\hline 8. & $\begin{array}{l}\text { Ippapuvu collected from the forest is used for extracting oil which is used for cooking } \\
\text { purpose. }\end{array}$ & 2.23 & $\mathrm{R}$ & NV \\
\hline 9. & The boiled Ippapuvu is consumed by the tribal farmers for healthy purpose. & 1.13 & IR & - \\
\hline 10. & $\begin{array}{l}\text { Wild Amla (Emblica officinalis) available from the forest is used for making pickles and } \\
\text { direct consuming for healthy purpose. }\end{array}$ & 2.13 & $\mathrm{R}$ & $\mathrm{V}$ \\
\hline 11. & $\begin{array}{l}\text { The liquid extracted from the Kodishaku is insecticidal when sprayed on infested paddy } \\
\text { fields, the insects where killed. }\end{array}$ & 0.84 & IR & - \\
\hline 12. & $\begin{array}{l}\text { Streaks of lightening in the East with rainbow in the west and high winds in the north would } \\
\text { lead to rain. }\end{array}$ & 0.78 & IR & - \\
\hline 13. & $\begin{array}{l}\text { As seen from the earth the moon and the Mirga star gaining together on the third day after } \\
\text { full moon day would lead to sufficient rains. }\end{array}$ & 0.98 & IR & - \\
\hline 14. & $\begin{array}{l}\text { Formation of a halo around the moon and the sun on frequent days does not cause wide } \\
\text { spread rains }\end{array}$ & 1.15 & IR & - \\
\hline 15. & $\begin{array}{l}\text { Sorghum seeds are stored in the gummis by mixing with ash and neem leaves sealed with } \\
\text { cow dung to avoid insect attack. }\end{array}$ & 1.49 & $\mathrm{R}$ & $\mathrm{V}$ \\
\hline 16. & $\begin{array}{l}\text { Kodishaku leaves are collected from the forest and incorporated in the field as green manure } \\
\text { it also controls burrows and sucking pests. }\end{array}$ & 2.52 & $\mathrm{R}$ & NV \\
\hline 17. & $\begin{array}{l}\text { The seeds chellaginjalu and musti ginjallu available from the forest are crushed and the } \\
\text { liquid extracted is used as an pesticide. }\end{array}$ & 1.09 & IR & - \\
\hline 18 & In drinking water they place chellaginjalu which removes poison and cleans the water. & 0.91 & IR & - \\
\hline 19. & $\begin{array}{l}\text { Musti ginjalu powdered is incorporated in the soil, for improving soil fertility and removes } \\
\text { alkalinity. }\end{array}$ & 2.23 & $\mathrm{R}$ & NV \\
\hline 20. & $\begin{array}{l}\text { Yerra thega }+ \text { cow dung ash }+ \text { neem leaf mixed and used for storing green gram, black gram, } \\
\text { cow pea and millets to avoid insect attack. }\end{array}$ & 2.13 & $\mathrm{R}$ & $\mathrm{V}$ \\
\hline 21. & The powdered Redgram leaf is used as feed for animals which is highly nutrious & 2.65 & $\mathrm{R}$ & $\mathrm{V}$ \\
\hline 22. & The sticks of Redgram is used as fuel as well as fencing & 2.23 & $\mathrm{R}$ & $\mathrm{V}$ \\
\hline 23. & Bottle gourd is cultivated as border crop around groundnut field to get additional income & 2.18 & $\mathrm{R}$ & V \\
\hline 24. & Pods of cow pea are sundried until they become brittle to make seed separation easily & 2.13 & $\mathrm{R}$ & V \\
\hline 25. & $\begin{array}{l}\text { Paddy straw is stored at certain height on bamboos made platforms to avoid softening and } \\
\text { animal feeding. }\end{array}$ & 2.71 & $\mathrm{R}$ & V \\
\hline 26. & $\begin{array}{l}\text { In Amavasya they store the seeds in gummies with ash and neem leaves to avoid insect } \\
\text { attack. }\end{array}$ & 2.52 & IR & NV \\
\hline 27. & Moktharam is a festival celebrated during the tholakari varsham for getting a good crop. & 0.84 & IR & - \\
\hline 28. & $\begin{array}{l}\text { During the month of May and June early hours 3-4 am they observe the stars in the sky if } \\
\text { they bend aside indicates the sign of rain. }\end{array}$ & 1.09 & IR & - \\
\hline 29. & $\begin{array}{l}\text { The pulses, cereals and millets are kept in different bowls according to seasons with water. } \\
\text { The seeds which immerse indicates the sign of rain at that season. If it does not immerse } \\
\text { indicates it may not rain that season. }\end{array}$ & 1.29 & IR & - \\
\hline 30. & Jowar and black gram seeds are mixed and sown with help of bamboo behind the plough. & 2.71 & $\mathrm{R}$ & V \\
\hline 31. & $\begin{array}{l}\text { The mixed seeds of jowar and blackgram intercropped with redgram } 4: 1 \text { ratio which } \\
\text { improves soil fertility and get additional income to the tribal farmers. }\end{array}$ & 2.34 & $\mathrm{R}$ & $\mathrm{V}$ \\
\hline
\end{tabular}




\begin{tabular}{|c|c|c|c|c|}
\hline 32. & $\begin{array}{l}\text { Intercultural operations and timely weeding done with a bamboo stick consists of sharp } \\
\text { bamboo teeth called Vakurupass (commonly called guntakas.) }\end{array}$ & 2.13 & $\mathrm{R}$ & $\mathrm{V}$ \\
\hline 33. & $\begin{array}{l}\text { In mixed crop of Korra }+ \text { Gamajonna Koma yields first followed by Gamajonna and finally } \\
\text { redgram to get additional income. }\end{array}$ & 2.03 & $\mathrm{R}$ & $\mathrm{V}$ \\
\hline 34. & $\begin{array}{l}\text { After harvesting of mixed crop maize }+ \text { Sama Jonna they raise rice and korra in } 4: 1 \text { was } \\
\text { practiced, which acts as crop rotation and improves soil status. }\end{array}$ & 2.41 & $\mathrm{R}$ & V \\
\hline 35. & $\begin{array}{l}\text { After harvesting of pedda jonna. Korra }+ \text { greengram }+ \text { blackgram were mixed and sown } \\
\text { which serves for the family purpose and also improves nutrient status of the soil. }\end{array}$ & 2.34 & $\mathrm{R}$ & V \\
\hline 36. & $\begin{array}{l}\text { Sheep penning and Cattle penning are practiced during summer for 2-3days in each field to } \\
\text { improve soil fertility }\end{array}$ & 2.31 & $\mathrm{R}$ & V \\
\hline 37. & $\begin{array}{l}\text { Tribals incorporate ash into the soil which belived to reclaim the soil gradually and improves } \\
\text { fertility. }\end{array}$ & 2.56 & $\mathrm{R}$ & NV \\
\hline 38. & $\begin{array}{l}\text { 3-4 ploughings for cultivation of ragi and } 2 \text { ploughings of cultivation of Sama, Korra, ganti } \\
\text { are sufficient. }\end{array}$ & 2.71 & $\mathrm{R}$ & V \\
\hline 39. & $\begin{array}{l}\text { Ploughing after every shower during the pre sowing season to conserve enough moisture for } \\
\text { the crop,remove weeds and ensure good crops. }\end{array}$ & 2.75 & $\mathrm{R}$ & V \\
\hline 40. & $\begin{array}{l}\text { Application of sand from river beds during summer is practiced to increase the fertility of } \\
\text { black soil. }\end{array}$ & 2.95 & $\mathrm{R}$ & V \\
\hline 41. & $\begin{array}{l}\text { Deep ploughing is practiced during summer to improve water holding capacity of soil and } \\
\text { conserve enough soil moisture. }\end{array}$ & 2.21 & $\mathrm{R}$ & V \\
\hline 42. & $\begin{array}{l}\text { Laying stone bunds around the fields across the slope for preventing erosion and for } \\
\text { conserving moisture is practiced. }\end{array}$ & 2.47 & $\mathrm{R}$ & V \\
\hline 43. & $\begin{array}{l}\text { Application of hill soil (Konda mannu)is practiced to increase the water holding capacity of } \\
\text { red soils. }\end{array}$ & 2.71 & IR & - \\
\hline 44. & Repeated ploughing is practiced to reduce weed population in dry lands. & 2.13 & $\mathrm{R}$ & - \\
\hline 45. & Profuse weed growth after rain is an indication for high soil fertility. & 1.91 & IR & - \\
\hline 46. & Ants change their eggs from one place to another which indicates initiation of rains. & 1.74 & IR & - \\
\hline 47. & It will rain if termite fly in large member in the air at $10-20 \mathrm{fts}$ height. & 1.89 & IR & - \\
\hline 48. & If the sky becomes dark near the horizone there will be instant rain. & 1.96 & IR & - \\
\hline 49. & Rain follows the frogs crocking & 1.78 & IR & - \\
\hline 50. & $\begin{array}{l}\text { Even the seeds are of good quality, they must be sown in the right season only to get higher } \\
\text { yields. }\end{array}$ & 2.71 & $\mathrm{R}$ & V \\
\hline 51. & $\begin{array}{l}\text { Intercultural operations and timely weeding are essential for rainfed agriculture thus } \\
\text { followed to possible extent }\end{array}$ & 2.34 & $\mathrm{R}$ & V \\
\hline 52. & $\begin{array}{l}\text { Sesamum is grown as summer crop preceding to paddy which give additional income and } \\
\text { returns. }\end{array}$ & 2.13 & $\mathrm{R}$ & V \\
\hline 53. & Collection and burning of insects is practiced by the farmers in initial stages of pest attack & 2.03 & $\mathrm{R}$ & V \\
\hline 54. & $\begin{array}{l}\text { A man like effigy made up rice straw wearing a dress is used to keep at the centre of the } \\
\text { field. The birds fly away because of human appearance in the field. }\end{array}$ & 2.41 & $\mathrm{R}$ & V \\
\hline 55. & Continuous drizzling encourages the spread of pest and disease. & 2.34 & $\mathrm{R}$ & V \\
\hline 56. & $\begin{array}{l}\text { Farmers used to stay in the field during nights to ward of wild animals and farm women } \\
\text { watches the field during day times }\end{array}$ & 2.75 & $\mathrm{R}$ & V \\
\hline 57. & Neem leaves are mixed with seeds and stored for long time which prevents pest attack. & 2.56 & $\mathrm{R}$ & V \\
\hline 58. & $\begin{array}{l}\text { Farmers used to store paddy and pulses in earthen pots or gunny bags kept on planks } \\
\text { suspended in the kitchen. They believe that the smoke emitted from chulhas during cooking } \\
\text { prevents storage pest attack }\end{array}$ & 2.45 & $\mathrm{R}$ & $\mathrm{V}$ \\
\hline 59. & $\begin{array}{l}\text { Storing food grains in big drums made up of clay and pasted with cow dung outside the } \\
\text { drum. }\end{array}$ & 2.41 & $\mathrm{R}$ & V \\
\hline 60. & $\begin{array}{l}\text { Harvested produce of millets in threshed by keeping the crop on the road and allowing the } \\
\text { vehicles to pass on it to separate the grain is practiced. }\end{array}$ & 1.14 & IR & - \\
\hline 61. & $\begin{array}{l}\text { Seed material stored in earthen post which is kept on the roof inside the house directly above } \\
\text { the furnace in the kitchen. The smoke acts as repellent to the insects. }\end{array}$ & 1.91 & IR & NV \\
\hline 62. & $\begin{array}{l}\text { Harvested turmeric is boiled in water and sun dried for } 15-20 \text { days and rubbed on soil to } \\
\text { make it ready for sale. }\end{array}$ & 2.73 & $\mathrm{R}$ & V \\
\hline 63. & $\begin{array}{l}\text { The graded turmeric is stored in gunny bags and kept on long benches to reduce storage pest } \\
\text { attack. }\end{array}$ & 2.52 & $\mathrm{R}$ & V \\
\hline
\end{tabular}


The ITK No 51 was judged as rational and valid ITK because intercultural operations and timely weeding are essential for rainfed agriculture to conserve soil moisture, weed free plot, improved aeration and crop growth.

The ITK No 52 was judged rational and valid ITK, sesamum is grown as summer crop preceding to paddy to get additional income which is useful for the tribal farmers to invest on paddy crop and the scientists also recommending the same practice for profitable agriculture.

The ITK No 53 was judged as rational and valid i.e. collection and burning of insects by the farmers in initial stages to avoid the spread of attack.

The ITK No 54 and 56 were judged rational and valid ITKs because man like effigy made up of rice straw wearing a dress and farmers night stay in field helps to scare away birds and wild animals.

The ITK No 55 was judged as rational and valid ITK because continuous drizzling encourages the spread of pest and disease.

The ITK No 57 and 58 were judged rational and valid ITKs because neem leaves contain an alkaloid azadirachtin which act as insect repellent. Hence mixing with seeds stored in earthen pots or gunny bags ensures prevention of pest attack.

The ITK No 62 and 63 were judged rational and valid because harvested turmeric is boiled for clean of mud as well as extraneous material and finally for curing. Turmeric is sundried for 15-20 days to make it ready for sale and stored in gunny bags and kept on long benches to reduce storage pest attack.

\section{References}

Ganesamoorthi, S. 2000. Indigenous knowledge on post-harvest practices. M.Sc. (Ag.) Thesis. Tamil Nadu Agricultural University, Coimbatore, India.

Lakshmana, K. 2000. Documentation and Analysis of Indigenous Farm Practices on major crops. An Inventory. M.Sc. (Ag.) Thesis. Tamil Nadu Agricultural University, Coimbatore, India.

Rajasekaran, B. and Whiteford, M.B. 1993. The role of indigenous knowledge in designing food security policies. Food Policy. 18(3): 237-247.

Sundaramari, M and Ranganathan, T. 2003. Indigenous Agricultural Practices for Sustainable Farming/ Jodhpur, Agrobios. 311-312.

\section{How to cite this article:}

Praveen, N., I. Sreenivasa Rao and Sudha Rani, V. 2018. Rationality and Validity of ITKs on General Agriculture by Tribal Farmers in Telangana Region. Int.J.Curr.Microbiol.App.Sci. 7(11): 34-39. doi: https://doi.org/10.20546/ijcmas.2018.711.006 